\title{
"This is absolutely gay!“ \\ - Homosexuality within the German Armed Forces
}

\section{By MARion NÄSER-LATHER}

\begin{abstract}
Drawing on Connell's theory of hegemonic masculinity and Foucault's concept of 'dispositive', this paper analyses historical and contemporary discourses on homosexuality within the Bundeswehr (German Armed Forces). I argue that the interconnected norms that shape the construction of homosexuality in the Bundeswehr - hegemonic masculinity as a core norm for male as well as female soldiers, and the dispositives of strength and equality - have different impacts on gay men and lesbians, empowering lesbian and devaluating gay soldiers. Through a discourse analysis of legal documents, internet forum discussions, drillmasters' utterances, and interviews with gay and lesbian soldiers, I show how these gender norms and dispositives reflect the experiences of homosexual soldiers as well as their coping strategies.
\end{abstract}

\section{KEYWORDS}

Bundeswehr, homosexuality, queerness, masculinity, lesbian soldiers, gay soldiers

Dr. Marion Näser-Lather is a researcher at the Centre for Gender Studies at Marburg University. Her current research interests include critical military studies, digitization, movement research, and Mediterranean Studies. 


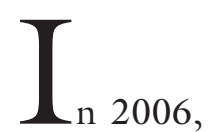

a law ensuring the equal treatment of male and female soldiers became effective in Germany. This law also aimed to prevent or eliminate discrimination based on sexual identity (Bundesministerium der Justiz und für Verbraucherschutz 2006, 1). However, in 2017, Captain Marcus Otto, chairman of the working group for homosexual personnel of the Bundeswehrl (German Armed Forces), stated that homosexuality still is a taboo topic, that homophobic remarks are part of his daily experiences, and that homosexual soldiers often do not dare to out themselves out of fear to be discriminated against, e.g. through negative evaluations (Stern 2017).

What are the reasons for this persisting discrimination? Drawing on Raewyn Connell's theory of hegemonic masculinity and Michel Foucault's dispositive concept, I will attend to the ongoing discrimination of lesbian and gay soldiers in the Bundeswehr. In the next two chapters I will outline how hegemonic masculinity and the interconnected dispositives of strength and of equality manifest themselves and how they shape military discourses on homosexuality in this context. In the following third chapter, I show that those norms have different effects for lesbian and gay soldiers with the dispositive of strength facilitating an integration of "butch" lesbian soldiers, who can thus converge on the ideal of hegemonic masculinity, and hindering, together with the dispositive of equality, the acceptance of gay and especially camp soldiers. To that end, I look at daily practices based on the experiences and coping strategies of homosexual soldiers.

Although scholars from different countries have looked at the situation of LGBT soldiers, especially in the U.S. (e.g. Belkin 2012; Herbert 1998; Rimmerman 1996; Sundevall and Persson 2016), until now the situation of LGBT soldiers in the Bun- deswehr has only been dealt with in a legal and psychiatric treatise (Lindner 1986) and in a paper on policy history (Storkmann 2018). The discoursivation of homosexuality and the experiences of gay and lesbian soldiers of the Bundeswehr have not been researched so far.

I want to approach these two dimensions based on a discourse analysis (Jäger 2009) of different empirical material: medical experts discussions of homosexuality in the Bundeswehr and related legal texts from 1980 to 2017; seven problem-centred interviews (Witzel 2000) with gay and lesbian soldiers conducted by me in $2011 ;^{2}$ the utterances of drillmasters as they appeared on the internet platform aganauten.de (hosted by former conscripts) in 2006; discussions on two open accessible German internet forums for soldiers and individuals interested in the military - soldatentreff.de and bundeswehrforum.de taking place between 2005 and 2008; and participant observation that I carried out as a reserve officer ${ }^{3}$ at different units.

\section{THE BundesWeHR:}

\section{GENDER NORMS AND DISPOSITIVES}

The Bundeswehr, founded in 1955, has about 178.000 professional soldiers (Bundeswehr.de 2018b). Conscription was abolished in 2011. From 1975 on, women were allowed to serve in the music corps and the medical units. Since 2001, they are allowed to serve in all units and positions. Ongoing discussions about homosexual soldiers tend to focus on men and thus lesbians have not been the topic of organizational discourse.

Socialization within the Bundeswehr implies warding off female traits and practicing what counts as hegemonic masculinity in the German military (Apelt 2006, 30). In this context, hegemonic masculinity is characterized by an ideal of the heterosexu- 
al, strong, and "real man". As such, hegemonic masculinity in the Bundeswehr is reestablished through social practices legitimizing such men's dominant positions and justifying the subordination of women and other marginalized masculinities, such as masculinities identified as homosexual (Connell 2015, 130f.). Hegemonic masculinity is socialized through bodily experiences (ibid., 182), e.g. formal services, sports, exercises, weapons training, and through performative speech acts like the following drillmaster utterance, which propagates an aggressive heterosexuality, objectifies and depreciates women: "You can say 'ok' to a slut with which you have agreed on a price. Here it is 'yes, sir!'”. The implied heterosexuality of the instructor in this utterance turns the recruits into objects and reifies the equation that to penetrate means to have power and to be penetrated leaves one in an inferior position, a dynamic also conveyed by another drillmaster utterance:

"My name is lance sergeant Meyer. I spell it out for you: (F)oxtrott - (U)nion - (C)harlie - (K)ilo!!!“ (Aganauten.de 2007).

This form of hegemonic masculinity is also reinforced by what can be called intra-organizational dispositives (Näser-Lather 2011). A dispositive is defined by Foucault as:

"a thoroughly heterogenous ensemble consisting of discourses, institutions, architectural forms, regulatory decisions, laws, administrative measures, scientific statements, philosophical, moral and philanthropic propositions - in short, the said as much as the unsaid" (Foucault 1977, 194-195).

The first dispositive that shapes soldiers' behaviour and that belongs to the core of soldierly identity is strength (Näser-Lather 2011, 114). Bodily as well as mental strength is regarded as a military necessity.
Strength manifests itself in the steeling of the body, through the bellowing of commands and marching in unison, in being able to execute an order despite adverse circumstances, and through the exercise of military power.

Another dispositive related to the necessities and organisational structure of the Bundeswehr is the dispositive of equality which implies that all soldiers have to dress the same, carry the same gear, sleep in the same accommodations, and share the same rights and duties (Näser-Lather 2011, 13lf.). The dispositive of equality supports confirmative behaviour and suppresses deviations. While it not necessarily always fits with the ideal of hegemonic masculinity in the Bundeswehr, it presupposes this ideal and serves to strengthen cohesion, which is seen as a necessity and which leads to the rejection of everything that is different including homosexuals and women (see also Connell 2015, 126).

Of course, the ideal of hegemonic masculinity in the Bundeswehr and the dispositives of strength and equality manifest themselves in varying degrees in the different branches and units. As I observed in a paratroopers unit, for example, the dispositive of strength is socialized through the use of louder voices, by cultivating a dashing way of moving, and by aspiring well trained and often muscular bodies, whereas in a media unit people tended to speak softer, move more "civilian-like", and also have more freedom to express themselves as individuals through more diverse hair-styles and by voicing their opinions more often. In the media unit the dispositive of equality was thus less pronounced as also one of my interviewees, Mrs. Bloch, remarked: "as a unit, we really have been colourful". In addition, the socialization into and the expression of hegemonic masculinity varies according to the individual and his or her post, e.g. whether his or her primary task is fighting (infantry, special forces) or a desk job (human resources manager). 
The manifestation of hegemonic masculinity and the dispositives of strength and equality are also dependant on occupational motivation. Among my interviewees, $53 \%$ had joined the armed forces due to a patriotic motivation while the other $47 \%$ saw the armed forces only as an opportunity to receive an education or to earn money among other reasons (Näser-Lather 2011, 147-149), with the first category more prone to develop a gender identity close to the military's ideal of hegemonic masculinity. Furthermore, the expression of the two core aspects of hegemonic masculinity strength and competence (see Connell 2015,108 ) - differs between ranks, with the masculinity of officers being more grounded on authority and those of the lower ranks more on bodily strength.

The ideal of hegemonic masculinity in the Bundeswehr has of course changed over time, reacting to societal discourses and needs. In an attempt to distance themselves from the Wehrmacht - under which name the German Armed Forces promoted the connection of heroism and soldierly violence during the Nazi regime (see Connell 2015,256 ) - the leaders of the Bundeswehr aimed to contain soldierly masculinity trough the concept of soldiers as "citizens in uniform" (Bundesministerium der Verteidigung 2008). With missions abroad gaining importance and the longfeared occurrence of combat situations increasing, Major General Hans-Otto-Budde for example postulated the archaic fighter as a new ideal (Winkel 2004). Also, the need to maintain a masculine identity after the opening of the Bundeswehr to women increased and strengthened the military ideal of hegemonic masculinity. On the other hand, both the experiences of traumatized soldiers returning from missions abroad and the presence of women soldiers have led to the acceptance of ways of soldiering that include the display of emotions.

\section{CONTRADICTORY PROCESSES OF OTHERING: THE DISCOURSIVATION OF GAY AND LESBIAN SOLDIERS}

Legal documents and discussions within the German military show how discourses around homosexuality developed from rejection to gradual tolerance of lesbian and gay soldiers within the Bundeswehr. Until 1980, people identified as homosexuals were dismissed out of so called health reasons. From 1980 on, they could be conscripted respectively hired as soldiers, but were excluded from promotion and advancement (Lindner 1986, 211f.). While paragraph 175 of the German criminal code had put homosexuality under penalty until 1994 when it was abolished, the equal treatment of lesbian and gay soldiers was first achieved with a decree in 2003 which stated that sexual behaviour of and between soldiers was "without relevance regarding disciplinary law" (Bundesminister der Verteidigung 2003). However, even after the decree took effect discrimination continued.

In the military discrimination of lesbian and gay soldiers several persisting discursive strands can be observed. They all relate to an effort to expel the undesirable (see Connell 2015, 89). The first strand of discourse configures the male homosexual as the pathologized 'other'. In 1966, medical specialists of the military depicted homosexual men as deviant, unstable, intellectually immature, and perverse individuals with personality features such as egotism, aggressiveness, fear, and dishonesty (Finger et al. $1966,22)$. These kinds of characterizations were also common 40 years later. An internet forum discussion in 2006 illustrates the fear of being labelled as homosexual. As part of this discussion a user asks whether one can be assigned the same room as one's schoolmate during service. To this another user answers that "it s best to add 'we are NOT gay' as otherwise rumours may arise." (Bundeswehrforum 2006).

The 'otherness' of homosexuality has to 
be warded off constantly, as also the utterances of drillmasters such as the following exemplify: "Guys, keep attention to the distance. $80 \mathrm{~cm}$ towards the person in front of you [while marching]. Closer is gay and farther is desertion!" (Aganauten.de 2007). Related to this discursive strand is the use of the attribute 'schwul' (gay) as a pejorative expression for military equipment. For example, in the internet forum soldatentreff.de in 2007, 'gay' is mentioned as a negative characteristic of a rifle (Soldatentreff.de 2007). In addition, the presence of gay soldiers is connected to the fear of the 'disruptive other' and to the fear of being contaminated. Since the 1960s, lesbians and gay men are thought of as endangering the cohesion, discipline, and combat power of the troops (Finger et al. 1966, 22; Lindner 1986, 21lf.). A statement by the chairman of the working group for homosexual members of the Bundeswehr, Sebastian Fröhlich, confirms that such prejudices continue to exist:

"Images of guys during Pride parades in vinyl, leather, high heels, and colourful, shrill, and feminine [dominate the discussions]. Or things like: he is not capable of this because he will start to cry at any moment" (Fröhlich).

Such images of "colourful, shrill" and "effeminate" gay men stand in stark contrast to the dispositives of strength and equality in the German military and thus turn gay men into the other of the good soldier.

The second discoursive strand depicts gay soldiers as weak, a common phenomenon in patriarchal cultures (see Connell 2015, 203). In 1999, the Military Federal Administrative Court argued that homosexual relationships between a superior and a subordinate:

"influenced the authority of the superior and the subordinate's willingness to obey [negatively]" (Zweiter Wehrdienstsenat 1999, 250).
Sebastian Fröhlich's quote above also points to the devaluation of characteristics identified as female as a constitutive element of prevailing military attitudes towards gay soldiers. Being seen as female or effeminate puts one in opposition to the dispositive of strength. As a result, soldiers positioned in this way are rejected, as a statement on an online Bundeswehr forum shows:

"We have someone in our unit who is gay. The problem is not that he is gay, but that he behaves totally camp" (Soldatentreff.de 2005a).

The aura of homosexuality can also "infect" a unit with the stigma of weakness which has to be countered by a display of strength, as another forum discussion shows. Here users discuss that two gay soldiers had been caught in bed together. As one user describes it, the company is dubbed as "pink" and ostracized as not being sufficiently soldierly as a consequence of the incidence. The company then reacts by installing a new company commander who "is a hard but just superior, and [who] has tightened the drill." (Soldatentreff.de $2005 \mathrm{~b}$ ). Thus due to the equation of homosexuality with weakness and due to the importance of the dispositive of strength, lesbian and gay soldiers are under pressure to only live certain aspects of their assigned queerness, namely those which correspond to the military ideal of hegemonic masculinity: the straight heterosexual man. A statement by a gay soldier in an online military discussion forum reflects this: "You also hear that gays are not able to endure. That is not true, I can endure a lot" (Soldatentreff.de 2005-2006). All but one of my interview partners tried to cultivate the ideal of hegemonic masculinity and did their best to avoid being seen as the camp gay men or the femme lesbian.

The third discursive strand is that of the insatiable gay man whose desire is uncontrollable and therefore must be feared. In 
this strand the image of the weak and effeminate faggot is complimented by its imagined flipside: the aggressive, virile savage that follows his sexual urges without self-restrain. This image equally challenges the dispositive of strength that heterosexual soldiers are connected with. In 1966, Rudolph Brickenstein, a military medical doctor described the behaviour of homosexual soldiers as being dictated by sexual urges and lust (Finger et al. 1966, 22), an image that still exists among German soldiers today. In an online Bundeswehr forum discussion a user vows to "throw" a "confessing homosexual" out of the shower because him being there would be sexual harassment (Soldatentreff.de 2006). Another user points out that he would not want to sleep in the same room with a gay soldier and that he, if he had to, would only do so "with my buttocks to the wall" (Soldatentreff.de 2007c).

Discourses in the Bundeswehr on lesbian soldiers are centred on the butch lesbian. Two discursive strands dominate: on the one hand, butch lesbians are seen as valuable assets, and on the other, as strange and un-womanly. The ideal of hegemonic masculinity and the dispositive of strength lead to the acceptance of the butch, strong, and masculine lesbian, and to the devaluation of "feminine" women, as the statement by the lesbian officer Mrs. Bloch about a fellow lesbian soldier shows:

"she is very masculine. (...) she is well accepted. (...) she does not flinch from (...) getting her hands dirty. (...) But if you make a fuss, Barbie-like (...) that has an impact on comradeship and it is not tolerated" (Mrs. Bloch).

Likewise, Sebastian Fröhlich points out that the term "Kampflesbe" (literally fighting lesbian or dyke) when used in the Bundeswehr to describe a female soldier implicated "rather recognition [than disavowal] in the sense of "finally a woman who stands her ground"'.
For women up to the rank of non-commissioned officers, cultivating this habitus of working-class men or men who are identified as masculine and strong are thought of as being more capable of soldierly abilities than women identified as feminine. In a forum discussion, a soldier writes:

"I definitely prefer a female comrade with short hair and (...) broad shoulders to an overdressed fashion chick (...) because I know that in an emergency, the one with the brought shoulders will carry me for a while, while the fashion chick won't (...) because she is not even capable of doing five regular push ups" (Soldatentreff.de 2005-2007).

This ideal of hegemonic masculinity is sustained and re-updated through daily work, practices, and imagined archetypes of being a soldier - like getting wounded during combat - how improbable this may be for the individual soldier.

On the other hand, lesbian soldiers are deprived of their female gender status. As Mrs. Bloch reports, lesbian soldiers are thought of as being "men haters" and "not real women". For female soldiers, the inseparable connection between hegemonic masculinity and strength leads to them never succeeding in meeting this norm while keeping a female gender identity; yet at the same time, lesbians who live up to the military ideal of hegemonic masculinity are also not conforming with traditional gender images which ascribe fragility and softness to women and courage and warriorhood to men (Fronhaus 1998; Seifert 1996, 95). Therefore, while on the one hand they are in part accepted as "one of the boys", on the other hand they are rejected. This is illustrated by the following statement by a soldier:

"You don $\mathrm{t}$ need to become female fighter (Kampfweib). (...) You can easily stay a woman - butches are also not accepted" (Bundeswehrforum.de 2009). 
The background for this precarious nonposition of lesbian soldiers is the constant (un)doing of gender which women in the Bundeswehr are subjected to. With the opening of all positions to women in 2001, gender norms have become more fluid while also having strengthened. The perceived endangerment of masculinity through the opening of the Bundeswehr to women was compensated by an enclosement of women in norms that reaffirm traditional gender roles. Besides describing the integration of female soldiers into the Bundeswehr with the help of essentialized images of men and women in an internal military document (Zentrum Innere Führung 2000), stereotypical role images are also promoted through regulations regarding the appearance of soldiers. Men are forbidden to wear long hair and jewellery while the same rule does not apply to women (Bundesminister der Verteidigung 1996, 114-119). Yet if women comply with these rules, they are rejected as being weak, disavowals which were especially prevalent in the early days of integrating women into the German Armed Forced (Näser-Lather $2011,142 \mathrm{f}$.). This dynamic might add to the assimilation pressure that female soldiers experience. Aside from one informant, who could be identified as traditionally female in attire and appearance, all lesbian soldiers I interviewed strived towards what could be called a traditional masculine appearance. The semantic field of 'the female' overlaps with the traits ascribed to gay men. Therefore, and because they are a minority of only $11,8 \%$ percent (Bundeswehr.de 2018a), female soldiers tend to hide their gender and tend to assimilate themselves to male gender norms in order to be accepted as soldiers (Näser 2010, 107, 113).

So, while discourses on lesbian and gay soldiers follow the constraints imposed by the dispositive of strength, resulting in lesbians being associated with strength and gay men with weakness, both are subjected to processes of othering. Yet how are these imaginations of and ascriptions to gay and lesbian soldiers reflected in these soldier's everyday experiences?

\section{EXPERIENCES AND COPING STRATEGIES OF LESBIAN AND GAY SOLDIERS}

The military ideal of hegemonic masculinity and the wish to fend off behaviour which does not comply with this norm, lead to homosexuality being tabooed. As Sebastian Fröhlich points out, the working group for homosexual soldiers in the Bundeswehr is never mentioned as a support resource and is often also not invited to official events. In addition, he also notes "a basic homophobic attitude" which manifests itself in personal comments, bullying, and even assaults. Yet the attitudes towards homosexual soldiers vary considerably between units. Sebastian Fröhlich states that in:

"the greater area of Cologne (...) it is absolutely normal that every unit of the Bundeswehr has a gay man or a lesbian. Well, there they live absolutely openly and without any problems (...) But those who serve in a smaller village and maybe even in a combat unit $(. .$.$) they don't dare to say anything (...)$ because outing themselves would be, I think, life-threatening for them" (Frölich).

The more the military ideal of hegemonic masculinity manifests itself in a unit, the more often homosexual soldiers seem to be discriminated against. Officer Vogel describes that when he and his partner were still students at the Bundeswehr University, they did not encounter any problems - the university being a place where strict military rules and habits are more loose (students don't wear uniforms and enjoy more freedom, their primarily occupation being learning). In contrast, sergeant Brand led a double life during his time in a paratroopers unit. Although he was received positively by his comrades when he outed himself 
in 2004, his superior called him "a disgrace for the troops" and gave him low evaluations even though he had always been rated as outstanding prior to him coming out. The superior also accused Mr. Brand wrongly of having sexually harassed a subordinate. As a result, gays and lesbian in his unit were afraid to out themselves. They feared disadvantages just as sergeant Brand had experienced them. After his transfer to a logistic unit, Mr. Brand did not encounter problems any longer. Him being gay did not matter to anyone and he felt totally accepted. The same goes for the lesbian couple Mrs. Meister and Mrs. Bloch who serve as officers in a media unit. Here, the dispositive of equality has less of an impact leading to a greater acceptance of gays and lesbians. They are invited to events together, and people congratulate them on their baby.

The daily situations of gay and lesbian soldiers in the Bundeswehr thus ranges from acceptance and curiosity to rejection and/or othering. Sometimes curiosity merges with exoticization and othering, and boundaries of intimacy are crossed, aggressively reasserting the ideal of hegemonic masculinity, as officer Mrs. Meister knows very well: "Well, I often get asked: did you have sex with a man? Or: did you have a dick in your hand yet?"

Other times, the perceived threat of deviance from gay and lesbian soldiers is countered by positioning them as part of the other cis-gender. Sergeant Brand, for example, was invited to come along to a male strip event with his female comrades: "there was a women's evening in this club and they had ordered a stripper, and the girls took me with them." Lesbian soldiers sometimes pursue this strategy themselves by trying to become "one of the boys", being part of the military community. Mrs. Meister explains:

"When I speak to [male] comrades, (...) I almost feel as a part of their group (...) [when] I say, wow, nice ass [about another female soldier]."

This behaviour also has the effect that she does not experience unwanted sexual attention that heterosexual female soldiers often encounter:

"I really enjoy working together with men because you can (...) make insinuating jokes, without me being labelled the 'mattress of the company'."

In contrast, Mrs. Bloch has made the experience that passing as "one of the boys" does not work: it comes to communicative ambivalences if she banters amicably with her male (heterosexual) comrades, and she is perceived as a potential sexual object. Her male comrades do not seem to take her sexual orientation seriously and interpret her way of interacting as an offer to initiate a sexual relationship.

The military ideal of hegemonic masculinity in connection with the dispositive of equality leads to assimilation pressure among gay and lesbian soldiers. This can even go as far as gay soldiers adopting a heterosexual identity. In an online forum a soldier writes:

"I'm gay, but when I entered the Forces, I did not out myself. Actually, I have become used to being hetero and even went to a brothel with the others $(. .$.$) this has made me$ straight" (Soldatentreff.de 2008).

Other soldiers hide their homosexuality permanently. Non-commissioned officer Mrs. Lehmann explains:

"I did not know how the others would react, and I simply was not strong enough to cope with [rejection] (...) I made the girlfriend into a boyfriend, or (...) simply said that I'm single" (Mrs. Lehmann).

Air force officer Mr. Maier handled his 
coming out differently depending on circumstances. He first outed himself in 2000 when a decree determined that sexual identity should have no influence on rank promotion and status (Generalinspekteur der Bundeswehr 2000). However, when he was assigned a leadership position at another location, he was not that open about being gay because he did not want:

"to compromise myself or to become vulnerable, because I was only 21, sergeant, leader of a sub-unit, and all group-leaders of mine were at least four or five years older" ( $\mathrm{Mr}$. Maier).

In accordance with the general attitude among soldiers in the Bundeswehr, Mr. Maier understood that being identified as gay would mark him as weak and would thus potentially also undermine his authority. Mrs. Lehmann deals differently with being lesbian. She does not care about the heteronormative prejudices and reactions of her comrades:

"I have a picture [of my partner] on my desk (...) [And when a superior asks] 'well, are you married' (...) I nonchalantly and cheerfully say: 'yes! (...) And when they ask: 'So, and what does your husband do?', then I say: 'well, my wife is a physiotherapist'" (Mrs. Lehmann).

Some soldiers try to proactively prevent homophobic reactions by not drawing attention to themselves. Mrs. Meister is more reserved towards female comrades, and Mrs. Bloch would never flirt with women: "I don't want that someone has the impression, Mrs. X is now fancying Mrs. Y." Mrs. Lehmann even tries to avoid having to take showers together with her fellow soldiers:

"I have always taken my shower after or before the others $(. .$.$) because I was afraid that$ the others somehow felt stared at by me.
When $(. .$.$) it could not be avoided, I show-$ ered with my eyes closed" (Mrs. Lehmann).

At the same time, lesbian and gay soldiers also employ irony or provocation. Mrs. Lehmann for example provokes through subtle offensive jokes:

"I also play nasty jokes on them (...) when they are in their office and change clothes (...) I say: yes, you don't have to get naked immediately" (Mrs. Lehmann).

Mrs. Meister chooses calculated provocation to counteract the power of the dispositive of equality. She points to the normalcy of queerness by openly displaying her sexual identification: "Especially in situations [when others are looking] you have to put your hand on your partner's butt/behind." Mrs. Meister also tries to modify gender norms and to oppose othering by undermining heteronormative assumptions and by expanding the spectre of liveable manifestations of femininity:

"I sometimes play with gender. I have bought a tailcoat (...) and I wear at least parts of it at official events with officers to break through their reserve a bit, and to demonstrate to them that there not only exists the little doll swaggering around in a Hugo-Boss-costume, but that there are also other kinds of women" (Mrs. Meister).

Her partner, Mrs Bloch, described the reactions to this kind of gender play as follows: "it is somehow accepted under the motto: well, this is not a real woman anyway." This kind of cross-dressing is thus handled, more often than not, through the exclusion of the deviant perceived woman from the category of femininity. Knowing very well that this is the case, Mrs. Meister reaffirms her insistence on the fluidity of gender through humour:

"Well, people know that I wear boxer shorts 
(...) when they ask me why I do that, I simply say: well, it's because I need the space for my genitals" (Mrs. Meister).

In contrast, Mr. Maier calls out discriminating behaviour. Describing how he reacts in situations in which homophobic remarks are made, he said:

"When someone says: Hey, look at the cocksuckers over there, then I simply say: I think you are crossing a line here. That is not okay. After all, there could be someone sitting here at the table who is gay. - Yes, but there isn't.

- Oh yes, there is" (Mr. Maier).

So, gay and lesbian soldiers employ strategies to cope with discrimination and othering. However, all of them remain attached to the ideal of hegemonic masculinity and the dispositive of strength insofar as the image of the masculinized gay man and that of the butch lesbian are promoted by gay and lesbian soldiers themselves.

\section{HOMOSEXUALITY AND WARRIORHOOD}

Similar to discourses in the U.S. (Rimmerman 1996, pos. 131), homophobic assumptions about gay men as weak, disruptive to cohesion, and a threat were used as arguments for their 'unfitness' for service since the foundation of the Bundeswehr. This othering of gay men seems similar to that of black soldiers and women in the U.S. forces up until the 1970s: blacks were figured as promiscuous and sexually aggressive, and women were seen as destroying cohesion because of introducing jealousy, rivalry and the loss of discipline (D'Amico 1996, 24-26). Thus, the pejorative configurations of non-white, feminine, and nonheterosexual marginalized bodies resemble each other, and while a connection between homosexuality and virility existed in antique Greece and in the masculinist movement of the 19th this is not the case in the Bundeswehr. ${ }^{4}$
My findings show that the influence of the military ideal of hegemonic masculinity and the dispositives of strength and equality lead to the rejection of what is perceived as female - camp gay men and feminine women - and to the (limited) acceptance of what is perceived as 'male enough' - gay men and lesbians who can pass as masculine. The Bundeswehr-version of military masculinity, which is characterized by the dispositives of strength and equality, thus unfolds normative power for all soldiers, male and female alike, stigmatizing soldiers who deviate from that normative framework of being a soldier. Yet while male homosexuality is constructed in opposition to this hegemonic version of military masculinity, female homosexuality is partly contained within it.

Because of how the dispositives of strength and equality play out in different units, attitudes towards gay and lesbian soldiers differ widely. The discrimination of gay and lesbian soldiers in the Bundeswehr nevertheless seems to exceed that in civil society, something that gay and lesbian soldiers themselves are aware of. Sebastian Fröhlich said that the organisational culture "always lags behind (...) in comparison to the normal, civil development." The military ideal of hegemonic masculinity and traditional gender norms are more pronounced in the Bundeswehr than in German civil society. While military masculinity still is idealized by society as a whole in the U.S. (Belkin 2012, 8), in Germany militarism and the image of the masculine warrior hero had been rejected after World War II (Näser-Lather 2018). This discrepancy between military and civil culture in Germany could, together with the aforementioned different occupational motivations of soldiers, account for part of the huge span of experiences that gay and lesbian soldiers have. In contrast to Sweden where the armed forces almost seem to have a pioneering role in implementing progressive gender norms and the inclusion of LGBT 
personnel (Sundevall and Persson 2016, $119,126)$, the Bundeswehr has only reluctantly dealt with changes of the male-centred, heteronormative organizational culture (Näser-Lather 2011, 21f, 142f.). As a consequence, the integration of LGBT personnel is not always supported.

However, gay and lesbian soldiers also subvert the dominant ideal of hegemonic masculinity through queering tactics of provocation. Queering is, as Judith Butler (1993, 177) states, "what upsets and exposes passing; it is the act by which the racially and sexually repressive surface of conversation is exploded". As such, queering opens niches in which heteronormative gender is subverted and delegitimized as part of the everyday life of being a soldier. In daily-life interaction, niches are opening up which subvert heteronormative gender stereotypes and which require their legitimation. Pointing to these dynamics and showing how gay and lesbian soldiers deal with the heteronormative violence of military culture, as was the aim of this paper, promises to contribute to the queering of militaristic gender norms in these terms.

\section{Notes}

1. This association, the Arbeitskreis Homosexueller Angehöriger der Bundeswehr e.V. (homepage: https://www.ahsab-ev.de/), was founded in 2002 and describes itself as the lobby for LGBTI persons in the Bundeswehr, fighting for equal opportunities and against discrimination.

2. Some of my interview partners were recommended to me by Sebastian Fröhlich, at that time chairman of the working group for homosexual members of the Bundeswehr. I also knew a lesbian couple from my $\mathrm{PhD}$ field research (Näser-Lather 2011), who made my project known to others. For my sample, I selected gay as well as lesbian soldiers from combat and support units. My interview partners were Sebastian Fröhlich

(01.05.2011); Mrs. Bloch and Mrs. Meister (25.03.2011); Mr. Brand (15.04.2011); Mr. Vogel (08.05.2011); Mr. Maier (01.05.2011); Mrs. Lehmann (06.05.2011). All names have been anonymized with the exception of Sebastian Fröhlich, who is a public figure.

3. I became reserve officer during my $\mathrm{PhD}$ project to be able to research the Bundeswehr from within.

4. In Greece, between the 7th and the 3rd century $\mathrm{BC}$, relationships between older males and younger boys functioned as rite de passage for the development of virtues and warrior skills, in Athens as well as in Sparta (Dover 1983, 23f., 32, 168f.). In this context, super-virile homosexual males were framed as examples and role models of masculinity, heroism and leadership (Bruns 2001, 92-99).

5. The forum does not exist anymore, offline-copy archived by the author.

\section{REFERENCES}

- Aganauten.de. 2007. AGA-Fun. Ausbildersprïche. [Online]. [22.07.2016] Available from: www.aganauten.de.

- Apelt, M. 2006. Militärische Sozialisation. In: Gareis, S., and Klein, P. eds. Handbuch Militär und Sozialwissenschaft. Wiesbaden: VS-Verlag, 26.39 .

- Belkin, A. 2012. Bring me men. Military Masculinity and the Benign. Facade of American Empire, 1898-2001. New York: Columbia University Press.

- Bulmer, S. 2017. Sexualities in State Militaries. In: Woodward, R., and Duncanson, C. eds. The Palgrave International Handbook of Gender and the Military. London: Palgrave McMillan, 163-176. - Bundesminister der Verteidigung. 1996. ZDv 37/10. Anzugsordnung für die Soldaten der Bundeswehr. Bonn: Bundesministerium der Verteidigung.

- Bruns, C. 2001. (Homo-)Sexualität als virile Sozialität. Sexualwissenschaftliche, antifeministische und antisemitische Strategien hegemonialer Männlichkeit im Diskurs der Maskulinisten 1880-1920. In: Heidel, U., Micheler, S., and Tuider, E. eds. Jenseits der Geschlechtergrenzen. Sexualitäten, Identitäten und Körper in Perspektiven von Queer Studies. Hamburg: Männerschwarm, 87-108.

- Bundesminister der Verteidigung. 2003. Erlass $B$ 173 zur ZDv14/3 "Sexuelles Verbalten von und zwischen Soldaten". Bonn: Bundesministerium der Verteidigung.

- Bundesministerium der Justiz und für Verbraucherschutz. 2006. Soldatinnen- und SoldatenGleichbehandlungsgesetz vom 14. August 2006 
(BGBl. I S. 1897, 1904), das zuletzt durch Artikel 4 des Gesetzes vom 31. Juli 2008 (BGBl. I S. 1629) geändert worden ist. [13.05.2016]. Available from: https://www.gesetze-im-internet.de/bundesrecht/soldgg/gesamt.pdf.

- Bundesministerium der Verteidigung. 2008. A2600/1 Zentrale Dienstvorschrift Innere Führung, Selbstverständnis und Führungskultur. Bonn: Bundesministerium der Verteidigung.

- Bundeswehr.de. 2018a. Frauen in der Bundeswehr: Leistung entscheidet, nicht das Geschlecht.

[Online]. [23.07.2018]. Available from: https:// www.bundeswehr.de/portal/a/bwde/start/streitkraefte/truppe/frauen/.

- Bundeswehr.de. 2018b. Stärke: Militärisches Personal der Bundeswehr. [Online]. [23.07.2018].

Available from: https://www.bundeswehr.de/portal/a/bwde/start/streitkraefte/grundlagen/staer $\mathrm{ke} /$.

- Bundeswehrforum.de. 2006. Besteht die Möglichkeit in der Stubeneinteilung mitzumischen? [Online]. [23.05.2016]. Available from:

http://www.bundeswehrforum.de/forum/index.php?topic $=7093 \cdot \mathrm{msg} 63728 \# \mathrm{msg} 63728$.

- Bundeswehrforum.de. 2009. Franen bei der Bundeswehr. [Online]. [22.01.2010]. Available from: http://www.bundeswehrforum.de/forum/laufbahn-und-karriere/frauen-bei-der-bundeswehr20717/.

- Butler, J. 1993. Bodies That Matter: On the Discursive Limits of "Sex". London: Routledge.

- Buzer.de. 2018. Gesetz zur Änderung wehrrechtlicher Vorschriften 2011 (Wehrrechtsänderungsgesetz 2011 - WehrRÄndG 2011). [Online]. [23.07.2018]. Available from:

https://www.buzer.de/sl.htm?g=WehrR\%C3\%84 $\mathrm{ndG}+2011 \& \mathrm{f}=1$.

- Connell, R. 2006. Der gemachte Mann. Konstruktion und Krise von Männlichkeiten. Wiesbaden: VS-Verlag.

- D Amico, F. 1996. Race-ing and Gendering the Military Closet. In: Rimmerman, C. A. ed. Gay Rights, Military Wrongs. Political Perspectives on Lesbians and Gays in the Military. New York: Routledge, 3-46.

- Dover, K. 1986. Homosexualität in der griechischen Antike. München: C.H. Beck.

- Finger, G. et al. 1966. Beurteilung der Webrdiensttanglichkeit und Dienstfäbigkeit Homosexueller. Bonn: Bundesministerium der Verteidigung. - Foucault, M. 1980. Power/Knowledge. Selected Interviews and Other Writings 1972-1977. Ed. by Colin Gordon. New York: Pantheon Books.

- Frohnhaus, G. 1998. Schwert in Frauenhand: Emanzipationsmodell oder Schreckensvision? In:
Fronhaus, G., Grotkamp-Schepers, B., and Philipp, R. eds. Schwert in Frawenhand. Weibliche Bewaffnung. Essen: Klartext-Verlag, 9-17.

. Generalinspekteur der Bundeswehr. 2000. Führungshilfe für Vorgesetzte "Umgang mit Sexualität". Bonn: Bundesministerium der Verteidigung - Jäger, S. 2009. Kritische Diskursanalyse. Eine Einführung. Münster: Unrast-Verlag.

Lindner, M. 1986. Homosexuelle in der Institution Bundeswehr: Wehrpsychiatrische, rechtliche und sozialpsychologische Aspekte eines Dilemmas. In: Gindorf, R. and Haeberle, E. eds. Sexualität als sozialer Tatbestand. Berlin und New York: de Gruyter, 211-232.

- Meyer-Zwiffelhoffer, E. 1995. Im Zeichen des Phallus. Die Ordnung des Geschlechtslebens im alten Rom. Frankfurt am Main: Campus.

- Näser-Lather, M. 2011. Bundeswehrfamilien. Die Perzeption von Elternschaft und die Vereinbarkeit von Familie und Soldatenberuf. Baden Baden: Nomos.

· Näser-Lather, M. 2018. Impeded Heroes. On the (self-) perception of German veterans. In: Daxner, M.; Näser-Lather, M., and Nicola, S.-L. eds. Conflict veterans. Discourses and Living Contexts of an Emerging Social Group. Newcastle upon Tyne: Cambridge Scholars Publishing, 110-133.

- Näser, M. 2010. 'Eine uniformierte Frau ist noch lange keine Soldatin'. Prozesse des (Un)Doing Gender in der Bundeswehr. In: Van Elsbergen, A. et al. eds. Ansichten, Einsichten, Absichten. Marburg: Förderverein der Marburger kulturwissenschaftlichen Forschung und Europäischen Ethnologie e.V., 103-118.

- Rimmerman, C.A. ed. 1996. Gay rights, military wrongs. Political perspectives on lesbians and gays in the military. New York: Routledge

- Schiesser, S. 2002. Gender, Medien und Militär: Zur Konstruktion weiblicher Stereotype in der Darstellung von Soldatinnen in den Printmedien der Bundeswehr. Beiträge zur feministischen Theorie und Praxis. 61, 47-61.

- Seifert, R. 1996. Militär - Kultur - Identität. Individualisierung und die soziale Konstruktion des Soldaten. Bremen: Ed. Temmen.

- Soldatentreff.de. 2007c. coming out beim Bund?5

- Soldatentreff.de. 2005a. schwul und beim Bund. Soldatentreff.de. 2005b. *16/*. Luftwaffenausbildungsregiment in budel ??

Soldatentreff.de. 2005-2007. Frawen in der Bundeswehr.

- Soldatentreff.de. 2006. Homosexuelle Soldatinnen.

- Soldatentreff.de. 2007a. Interessante Waffen im Einsatz. 
- Soldatentreff.de. 2008. schwule Soldaten. - Stern. 2017. Das Tabu Homosexualität in der Bundeswehr. [Online]. [22.01.2018]. Available from:

https://www.stern.de/panorama/gesellschaft/bu ndeswehr-das-tabu-homosexualitaet-in-dertruppe-7308042.html.

. Storkmann, K. 2018. Das große Tabu. Homosexuelle Soldaten in der Bundeswehr von 1955 bis zum Jahr 2000. In: Pieken, G. ed. Gewalt und Geschlecht. Männlicher Krieg - weiblicher Frieden? Dresden: Sandstein Verlag, 288-299.
- Sundevall, P. and Persson, A. 2016. LGBT in the Military: Policy Development in Sweden 19442014. Sex Res Soc Policy 13, 119-129.

- Witzel, A. 2000. Das Problemzentrierte Interview. Forum Qualitative Sozialforschung. [Online]. [13.09.2017]. Available from: http://www.qualitative-research.net/fqs-texte/1-00/1-00witzeld.htm.

- Zweiter Wehrdienstsenat. 1999. Urteil des zweiten Wehrdienstsenates vom 23.2.1999, 2 WD 15.98, NZWehrr. 6, 250-55. 